\title{
Cervical cytology profile by Papanicolaou smear in a rural setting in mid-Kerala
}

\author{
Megha Jayaprakash $^{1 *}$, Sreenija Menon', Georgy Joy Eralil², Alok K. P. ${ }^{3}$, Rajany Jose ${ }^{3}$
}

\begin{abstract}
${ }^{1}$ Department of Obstetrics and Gynecology, Government Medical College, Thrissur, Kerala, India ${ }^{2}$ Department of Obstetrics and Gynecology, Sreenarayana Institute of Medical Sciences, Kerala, India ${ }^{3}$ Department of Community Medicine, Government Medical College, Thrissur, Kerala, India
\end{abstract}

Received: 25 August 2020

Revised: 09 September 2020

Accepted: 10 September 2020

\section{*Correspondence:}

Dr. Megha Jayaprakash,

E-mail:meghajayaprakash@yahoo.co.in

Copyright: (c) the author(s), publisher and licensee Medip Academy. This is an open-access article distributed under the terms of the Creative Commons Attribution Non-Commercial License, which permits unrestricted non-commercial use, distribution, and reproduction in any medium, provided the original work is properly cited.

\section{ABSTRACT}

Background: With no systematic national screening programme, the rates of cervical epithelial cell abnormalities as reported by various studies range from $1.32 \%$ to $25 \%$ in India. Majority are epithelial squamous cell abnormalities that include atypical squamous cells of undetermined significance (ASCUS) and low-grade squamous intraepithelial lesion (LSIL). Worldwide incidence of adenocarcinoma and its precursors have increased over past few decades. Objectives were to study the clinical and cervical cytological profile among women attending camps in rural areas of Thrissur district of Kerala.

Methods: A cross sectional study was conducted in 214 women in the 25-65 years age group who attended cancer screening camps in rural areas of Thrissur district. Papanicolaou (Pap) smear was done using standard technique and reported using latest Bethesda classification. Pap smear results were considered as abnormal when the report was ASCUS, atypical glandular cells of undetermined significance, LSIL, high grade squamous intraepithelial lesion or invasive lesion.

Results: Of all the smears, $41.6 \%$ were negative for intraepithelial lesion or malignancy. Inflammatory smears (nonspecific and specific infection associated) were seen in $57 \%$. Glandular cell abnormality was found in $1.4 \%$ and these women were in 31-50 years age group. Among patients with glandular cell abnormality most common symptom was discharge per vaginum.

Conclusions: The results of this study may be a pointer to an increase in glandular cytological abnormalities in our population and needs further large-scale studies to confirm. Current screening methods of Pap smear alone may not be adequate to pick up these lesions.

Keywords: Pap smear, Atypical glandular cells, Cervical cytological profile

\section{INTRODUCTION}

Globocan 2018 figures show that worldwide cervical cancer is the fourth leading female cancer both in incidence and mortality. India has the maximum number of deaths $\left(60,000 /\right.$ year) in the world. ${ }^{1}$ In India cervical cancer is the second most common cancer in women aged between 15-45 years and more than 436 million women aged 15 years or more are at risk. ${ }^{2}$
Cervical cancer can be diagnosed at the pre-invasive stage with adequate and repetitive cytological screening with Papanicolaou (Pap) smears. ${ }^{3}$ But there is very little awareness about screening or prevention of cervical cancer, even in Kerala, which is the most literate state of India. Only $2.3 \%$ women were aware of cervical Pap smear screening in a study among rural women attending camps in central Kerala. ${ }^{4}$ In developed countries, populationbased screening has decreased the annual incidence and 
prevalence of cervical cancer by $50-70 \% .^{5}$ It is possible to detect the cancer in early stages thereby reducing mortality and morbidity by proper screening for cervical cancer. ${ }^{6}$

Corresponding reduction in incidence of cervical adenocarcinoma has not been reported as a result of cervical screening strategies. In fact the proportion of adenocarcinoma to squamous carcinoma has doubled over the past few decades and current screening practices may not be adequate to pick up the precursor lesions for adenocarcinoma. ${ }^{7}$ A Canadian study reported that the incidence of cervical adenocarcinoma increased 3 fold in the age group 20-34 years and 2 fold in the age group 35 49 years. $^{8}$

With the absence of a systematic national cervical screening programme, the prevalence of cervical epithelial abnormalities reported by various studies in India ranges from $1.32 \%$ in Ahmedabad to $25 \%$ in Guwahati. ${ }^{9,10}$

Traditionally atypical glandular cells (AGC) is considered an uncommon cytologic diagnosis, occurring in approximately 0.18 to $0.74 \%$ of cervical smears. But it requires detailed evaluation since 20 to $50 \%$ will harbour significant histologic abnormalities, such as cervical intraepithelial neoplasia, adenocarcinoma in situ or adenocarcinoma of cervix or endometrium. ${ }^{11}$

There is no study in published literature which has documented the cytological profile of cervical smear in women of Thrissur district of Kerala. The present study was undertaken with the objective to identify clinical and cytological profile among women attending screening camps.

\section{METHODS}

This cross-sectional observational study has been carried out in 214 women in the 25-65 years age group who attended cancer screening camps conducted by GMC Thrissur and SNIMS in rural coastal areas (selected wards of Thalikulam, Edamuttam and Thriprayar) of Thrissur district between June to December 2017 and who consented to the study. Women who had a prior Hysterectomy and no cervix were excluded from the study. History and clinical symptoms were collected using a questionnaire that was peer reviewed and tested.

After informed consent, all the women were clinically examined and pap smears with Ayre's spatula and cytobrush were obtained. The cytological diagnosis after examining the pap smears were obtained at a certified lab and was reported by the same pathologist using latest Bethesda 2014 classification. Pap smear results were considered as abnormal when the report was atypical squamous cells of undetermined significance (ASCUS), low-grade squamous intraepithelial lesion (LSIL), high grade squamous intraepithelial lesion (HSIL), AGC or invasive lesion. The data was entered in Microsoft Excel and was analyzed by calculating percentages.

\section{RESULTS}

A total of 214 women in the age group 25-65 years who underwent screening by conventional Pap technique were included in the study. In the study majority of women were in the age group between 30 to 50 years $(65.9 \%)$. Almost three fourth women $(71.96 \%)$ had a parity of 1 or 2 (Table 1).

Table 1: Demographic variables.

\begin{tabular}{|lll|}
\hline Variables & Number & Percentage \\
\hline Age group (years) & & \\
\hline$<30$ & 5 & 2.3 \\
\hline $30-50$ & 141 & 65.9 \\
\hline$>50$ & 68 & 31.8 \\
\hline Education & & \\
\hline Uneducated & 4 & 1.86 \\
\hline School & 167 & 78.03 \\
\hline Graduate & 43 & 20.09 \\
\hline Parity & & \\
\hline Nulliparous & 7 & 3.27 \\
\hline 1 or 2 & 154 & 71.96 \\
\hline$>2$ & 53 & 24.76 \\
\hline
\end{tabular}

$41.6 \%$ of smears were negative for intraepithelial lesion or malignancy (NILM). Inflammatory (both nonspecific and those associated with specific infections like bacterial vaginosis, Trichomonas vaginalis and Candida) smears were seen in $57 \%$ and atypical glandular cells was found in $1.4 \%$ (Figure 1).

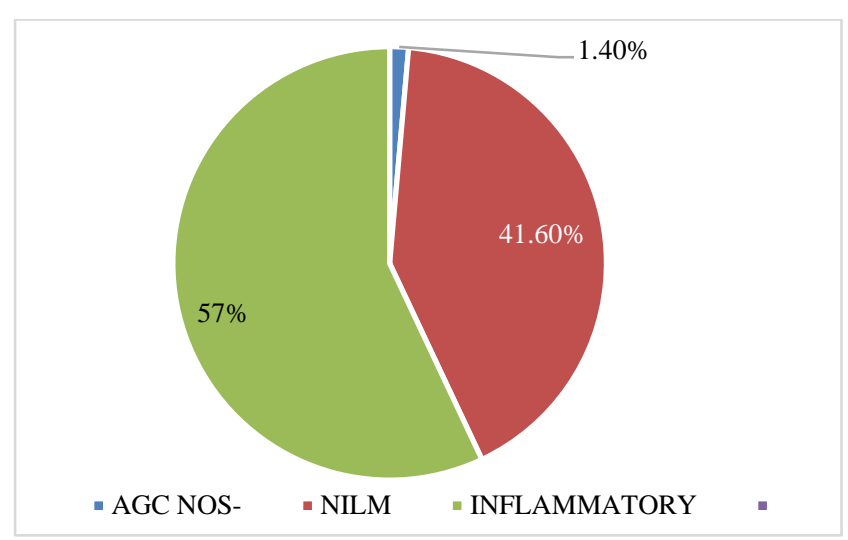

Figure 1: Distribution of patients according to Pap smear findings.

Among inflammatory smears, $33.6 \%$ were in the age group 31-50 years. All the patients with glandular cell abnormality were in the age group 31-50 years (Table 2).

Among 3 persons with glandular cell abnormality most common symptom was discharge PV. Major symptoms reported in the study population were discharge per vaginum (discharge PV) and postmenopausal bleeding. Majority of women with discharge PV (29.4\%) had an inflammatory smear report (Table 3). 
Table 2: Distribution of cervical smear finding with age.

\begin{tabular}{|llllll|l|}
\hline \multirow{2}{*}{ Age range (years) } & NILM & \multicolumn{3}{c}{ Inflammatory } & \multicolumn{3}{c|}{ AGC } \\
\cline { 2 - 3 } & Number & $\mathbf{\%}$ & Number & $\mathbf{\%}$ & Number & \% \\
\hline$<\mathbf{3 0}$ & 3 & 1.4 & 2 & 0.9 & 0 & 0 \\
\hline $\mathbf{3 1 - 5 0}$ & 66 & 30.8 & 72 & 33.6 & 3 & 1.4 \\
\hline$>\mathbf{5 0}$ & 20 & 9.3 & 48 & 22.4 & 0 & 0 \\
\hline
\end{tabular}

Table 3: Distribution of cervical smear findings with clinical symptoms.

\begin{tabular}{|c|c|c|c|c|c|c|c|c|}
\hline \multirow[t]{2}{*}{ Symptoms } & \multicolumn{2}{|c|}{ NILM } & \multicolumn{2}{|c|}{ Inflammatory } & \multicolumn{2}{|c|}{$\begin{array}{l}\text { AGC NOS (not } \\
\text { otherwise specified) }\end{array}$} & \multicolumn{2}{|l|}{ Total } \\
\hline & Number & $\%$ & Number & $\%$ & Number & $\%$ & Number & $\%$ \\
\hline Postcoital bleeding & 0 & 0 & 3 & 1.4 & 0 & 0 & 3 & 1.4 \\
\hline Postmenopausal bleeding & 4 & 1.85 & 6 & 2.78 & 1 & 0.47 & 11 & 5.1 \\
\hline Discharge PV & 27 & 12.6 & 63 & 29.4 & 2 & 0.9 & 92 & 43 \\
\hline
\end{tabular}

\section{DISCUSSION}

Traditionally AGCs is a relatively uncommon cytologic diagnosis occurring in approximately 0.18 to $0.74 \%$ of cervical smears. ${ }^{11}$ The profile of cervical cytology in our study population was slightly different from similar studies in that the predominant abnormal smear after inflammatory was AGCs (1.4\%). These AGCs were seen in the 31-50 years age group.

The predominant smear report in our study was inflammatory (both nonspecific and specific infections) $(57 \%)$ which is similar to a south Indian hospital-based study on cervical cytology by Pap smear in symptomatic women. In that study, white discharge PV was the predominant symptom $(52.6 \%)$ and majority of patients $(88 \%)$ had an inflammatory smear. The incidence of ASCUS was 5\% and there were no AGCs. ASCUS, LSIL and HSIL mainly presented with white discharge. ${ }^{12}$

In a camp-based Pap smear screening done in Delhi also the most common symptom reported was white discharge PV $(28.5 \%)$ and the incidence of premalignant lesions in smear report was $4.6 \%$ with no AGCs. ${ }^{13}$

In a north Indian hospital-based study of pap smears done in 7127 women, there were $2 \%$ abnormal epithelial smears of which LSIL was the most common and there were no glandular cell abnormalities. Two thirds of abnormal smears were seen in women aged more than 40 years. ${ }^{14}$

In a South Indian hospital-based study of 500 women, white discharge PV was seen in $30 \%$ and there were $8.4 \%$ cervical squamous cell abnormalities, of which ASCUS was predominant. There were no AGCs reported. ${ }^{15}$ ASCUS was the predominant abnormal cervical smear report $(3.5 \%)$ in a study conducted in Meghalaya and there were no glandular cell abnormalities detected. ${ }^{16}$

In a study done among 3059 women in a tertiary hospital in North Kerala the percentage of epithelial abnormalities in Pap smears was $2.15 \%$ of which LSIL was predominant $(1.01 \%)$ and there were no AGCs. ${ }^{3}$

Our finding of $1.4 \%$ atypical glandular endocervical cells is slightly higher than that reported in a south Indian hospital-based study of 1000 women. In their study the most common abnormal smear was inflammatory (53.1\%). The incidence of premalignant lesions was $3.5 \%$ of which LSIL was the most common (2\%). There was $0.3 \%$ AGCs. ${ }^{17}$

But most of the studies done in developed countries have consistently reported the presence of AGCs.

Our finding of $1.4 \%$ is more than $0.2 \%$ AGC found in a large study done in Japan and reported in 2019. ${ }^{18}$ The incidence of AGC in a 10 year analysis of conventional Pap smears in Luxembourg was $0.05 \% .^{19}$

Out of 39,484 Pap smears, the percentage of AGUS cells was $1.2 \%$ in a study published in 1998 , which is fairly similar to our study. ${ }^{20}$

This trend in the present study conducted in rural areas of Thrissur, Kerala, India, may be a reflection in our population of increased incidence of AIS and adenocarcinoma worldwide over the past decades. It may also be due to more effective use of the cytobrush in sampling endocervical cells.

\section{Limitations}

It was a small cross-sectional study conducted among women attending camps from nearby rural areas. The final outcome after further histological diagnosis is not known.

\section{CONCLUSION}

The results of this study may be a pointer to an increase in glandular cytological abnormalities in our population and needs further large scale studies to confirm. Current 
screening methods of Pap smear alone may not be adequate to pick up these lesions.

\section{ACKNOWLEDGMENTS}

Authors would like to thank all residents and house officers of Department of Obstetrics and Gynaecology, GMC, Thrissur and SN Medical College, Aluva who actively participated in the camps. They would also like to thank the Department of Community Medicine, GMC, Thrissur for their support.

Funding: No funding sources

Conflict of interest: None declared

Ethical approval: The study was approved by the Institutional Ethics Committee

\section{REFERENCES}

1. Arbyn M, Weiderpass E, Bruni L, de Sanjosé S, Saraiya M, Ferlay J, Bray F. Estimates of incidence and mortality of cervical cancer in 2018: a worldwide analysis. Lancet Glob Health. 2020;8:191-203.

2. National Health Portal of India. Cervical Cancer: Introduction. 2016. Available at: https://www.nhp. gov.in/disease/reproductive-system/femalegynaecological-diseases-/cervical-cancer. Accessed on: 02 September 2020.

3. Thomas EE, Kumaran JA. Profile of PAP smears done in a tertiary centre in North Kerala. Int J Community Med Public Health. 2018;5:1974-9.

4. Jayaprakash M, Eralil GJ, Jose R, Radha KR, Vijilakshmi AG, Ambikabhai PG. Study on knowledge and practice of screening for cervical cancer among women from rural communities in central Kerala, India. Int J Reprod Contracept Obstet Gynecol 2018;7:4165-70.

5. Department of Cytology and Gynecological Pathology, Post Graduate Institute of Medical Education and Research, Chandigarh I. Guidelines for Cervical Cancer Screening Programme. 2006. Available at: http://screening.iarc.fr/doc/WHO_ India_CCSP_guidelines_2. Accessed on: 04 September 2020.

6. Nandakumar A, Gupta PC, Gangadharan P, Visweswara RN. National Cancer Registry Programme (NCRP-ICMR): Development of an atlas of cancer in India. First All India Report, 2001-2002. Bangalore: NCRP. 2010;1-2.

7. Smith HO, Tiffany MF, Qualls CR, Key CR. The rising incidence of adenocarcinoma relative to squamous cell carcinoma of the uterine cervix in the United States-a 24-year population-based study. Gynecol Oncol. 2000;78(2):97-105.
8. Liu S, Semenciw R, Mao Y. Cervical cancer: the increasing incidence of adenocarcinoma and adenosquamous carcinoma in younger women. CMAJ. 2001;164(8):1151-2.

9. Kothari S, Gohel A, Dayal A, Shah R, Patel S. Pap smear-A tool for detection of cervical intraepithelial lesions in health check-up schemes: A study of 36,740 cases. Int J Res Med. 2014;3(2):12-5.

10. Alakananada A, Sarma U, Biswas I. Histopathological Correlation with Cervical Cytology. IOSR J Dent Med Sci. 2016;15(11):2279-861.

11. Kim TJ, Kim HS, Park CT, Park IS, Hong SR, Park JS, et al. Clinical evaluation of follow-up methods and results of atypical glandular cells of undetermined significance (AGUS) detected on cervicovaginal Pap smears. Gynecol Oncol. 1999;73:292-8.

12. Thobbi VA, Khan F. Cervical cytology by Pap smear in reproductive population. Int $\mathrm{J}$ Reprod Contracept Obstet Gynecol. 2018;7:198892.

13. Sharma P, Rahi M, Lal P. A community-based cervical cancer screening program among women of Delhi using camp approach. Ind J Comm Med. 2010;35(1):86.

14. Malpani G, Agrawal P, Varma AV, Khandelwal N, Tignath G. Cervical Pap smear study and detection of abnormal epithelial lesions and determination of its accuracy by cytohistological correlation in patients of tertiary care teaching hospital in central India. Int $\mathbf{J}$ Reprod Contracept Obstet Gynecol. 2016;5:2312-6.

15. Rani BS. Cervical Pap Smear Study for Screening of Pre-Cancerous Conditions of Cervix. IAIM. 2018;5(1):138-44.

16. Mishra P, Thapa R, Dinkar AK. A study on cervical cancer screening using pap smear in urban area in state of Meghalaya, India. Int J Reprod Contracept Obstet Gynecol. 2018;7:3113-6.

17. George P, Rao S. Cytology of Uterine Cervix by Pap Smear: A Study from South India. J Evol Med Dent Sc. 2014;3(63):13796-803.

18. Toyodaa S, Kawaguchib R, Kobayashiba $\mathrm{H}$. Clinicopathological Characteristics of Atypical Glandular Cells Determined by Cervical Cytology in Japan: Survey of Gynecologic Oncology Data from the Obstetrical Gynecological Society of Kinki District, Japan. Acta Cytologica. 2019;63:361-70.

19. Scheiden R, Wagener C, Knolle U. Atypical glandular cells in conventional cervical smears: incidence and follow-up. BMC Cancer. 2004;4:37.

20. Bennett BB, Takezawa K, Wilkinson EJ, Drew PA, Hardt NS. Atypical glandular cells of undetermined significance and other glandular cell abnormalities in a high-risk population. J Lower Gen Tract Dis. 1998;2:132-5.

Cite this article as: Jayaprakash M, Menon S, Eralil GJ, Alok KP, Jose R. Cervical cytology profile by Papanicolaou smear in a rural setting in mid-Kerala. Int J Reprod Contracept Obstet Gynecol 2020;9:4000-3. 